\title{
Enthesitis and Dactylitis in Psoriatic Disease: A Guide for Dermatologists
}

\author{
Jerry Bagel ${ }^{1}$. Sergio Schwartzman ${ }^{2}$
}

Published online: 16 August 2018

(c) The Author(s) 2018

\begin{abstract}
Psoriatic arthritis (PsA) is an inflammatory arthritis that is estimated to affect approximately $30 \%$ of patients with psoriasis. Enthesitis and dactylitis, two hallmarks of PsA, are associated with radiographic peripheral/axial joint damage and severe disease. Clinical symptoms of enthesitis include tenderness, soreness, and pain at entheses on palpation, whereas dactylitis is recognized by swelling of an entire digit that is different from adjacent digits. Both ultrasound and magnetic resonance imaging can be used to diagnose enthesitis and dactylitis, especially in patients in whom symptoms may be difficult to discern. Delayed treatment of PsA can result in irreversible joint damage and reduced quality of life. Thus, it is recommended that dermatologists monitor patients with psoriasis for these two early and important manifestations of PsA.
\end{abstract}

\section{Key Points}

Psoriatic arthritis (PsA) affects approximately $30 \%$ of patients with psoriasis.

Enthesitis and dactylitis are associated with severe PsA disease.

Efforts should be made to enhance awareness of PsA symptoms in dermatology practices, particularly enthesitis and dactylitis, to improve early disease identification and help prevent long-term joint damage.

\section{Introduction}

Patients with psoriatic disease commonly present with skin lesions followed by musculoskeletal signs and symptoms [1]. Although dermatologists are familiar with skin lesions of psoriasis, they may not be as familiar with musculoskeletal manifestations of psoriatic arthritis (PsA). Unmet needs

Jerry Bagel

dreamacres1@aol.com

1 Psoriasis Treatment Center of Central New Jersey, 59 One Mile Road Ext. Suite G, East Windsor, NJ 08520, USA

2 Hospital for Special Surgery, New York, NY, USA in screening, assessing, diagnosing, and treating PsA have been identified [1, 2]. Inflammatory arthritis and the consequent diagnosis of PsA are common in psoriasis, and an estimated $30 \%$ of patients with psoriasis may have PsA [1]. Although PsA is typically diagnosed by a rheumatologist, dermatologists should be aware of PsA signs and symptoms because nearly $52 \%$ of patients with psoriasis have joint pain (which can also be caused by osteoarthritis and fibromyalgia [centralized pain syndrome]) without a diagnosis of PsA, and the average diagnostic delay for PsA in a combined population of patients with or without psoriasis was 5 years $[2,3]$. Additionally, a recent study indicated that arthralgia is a predictor of PsA (hazard ratio [HR] 2.59; $p=0.02$ ) in women with psoriasis [4].

PsA is a form of spondyloarthritis (SpA) that classically develops in psoriasis [5], typically between the ages of 30 and 50 years, although it can present at any time $[5,6]$. While most patients develop PsA after psoriasis (approximately 10 years later), some develop PsA before or concurrently with psoriasis [6-11]. PsA manifests as peripheral arthritis, enthesitis, dactylitis, and spondylitis (see Glossary) [5, 12]. Additional manifestations include nail lesions such as onycholysis and dystrophy (psoriatic onychodystrophy), pitting, and hyperkeratosis [5, 12]. Ultimately, PsA can negatively impact quality of life (QoL), functionality, productivity, and morbidity and increase mortality [3, 5, 12-15]. 

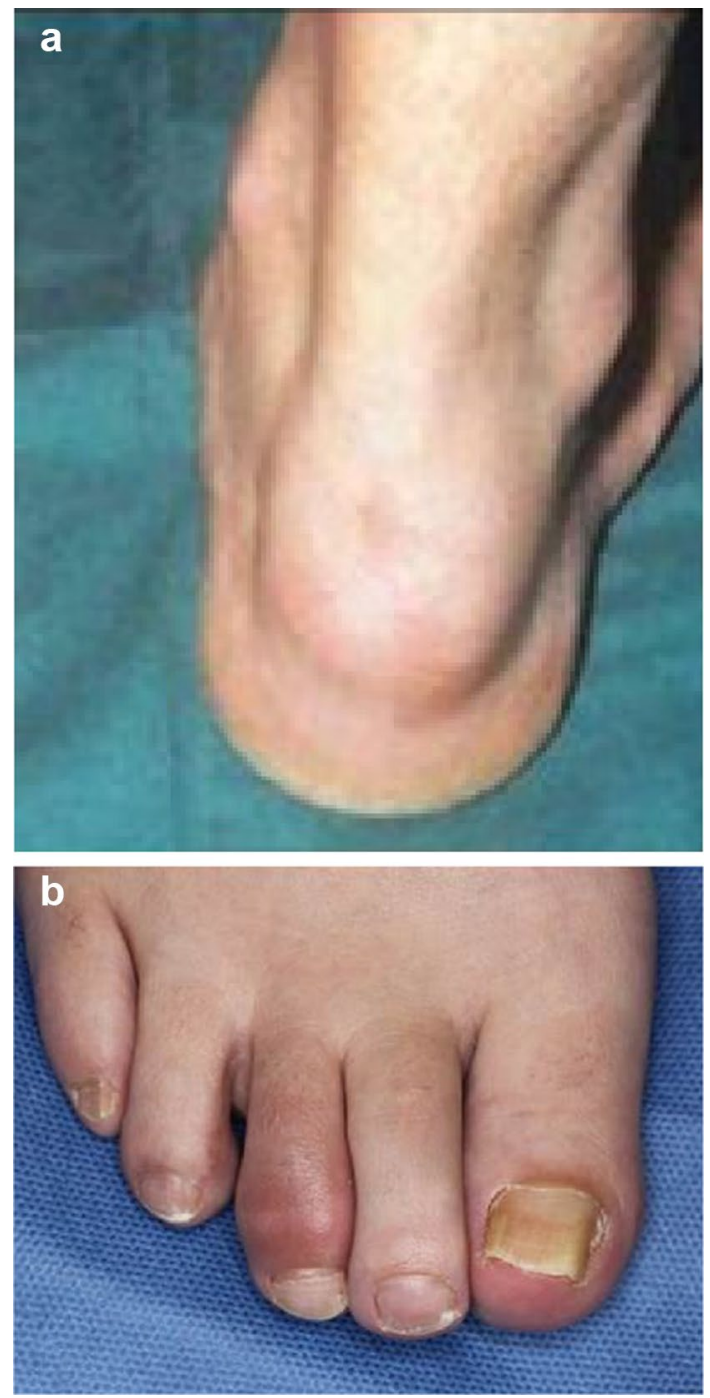

Fig. 1 Enthesitis and dactylitis. a Achilles tendon enthesitis (republished with permission of Dove Medical Press, from Kivelevitch et al. [95]). b Toe dactylitis. Republished with permission of Dove Medical Press, from Yamamoto [28])

Enthesitis and dactylitis (Fig. 1) are periarticular PsA manifestations that can be identified during clinical evaluation, and both are included in the Classification Criteria for Psoriatic Arthritis (CASPAR) as hallmarks of PsA (Table 1) [12]; however, these manifestations are frequently missed by dermatologists and rheumatologists. Enthesitis is present in $35 \%$ of patients with PsA, and dactylitis occurs in approximately $50 \%$ of patients with PsA [10, 16-18]. Peripheral enthesitis, dactylitis, or both can be present in isolation for months to years in a small number of patients [19]. Although the differential diagnosis of dactylitis includes several diseases, PsA is a common cause.

Enthesitis can sometimes be difficult to distinguish from extra-articular pain (i.e. tender points) in fibromyalgia and from joint pain associated with other rheumatic diseases, such as rheumatoid arthritis (RA) [20, 21]. However, dactylitis is not seen in fibromyalgia or RA [22-24], but can occur in gout, sarcoidosis, syphilis, tuberculosis, flexor sheath infections, and sickle cell disease [25]. The presence of enthesitis and dactylitis with additional clinical, laboratory, and imaging assessments can help distinguish PsA from other conditions with similar signs and symptoms $[5$, $6,22,26]$.

Because dermatologists refer $23 \%$ of patients with PsA for rheumatology evaluation, they have the potential to play an important role in managing PsA [27]. Rheumatologists can then provide specific treatment for arthritis, dactylitis, and enthesitis. Per American Academy of Dermatology guidelines, dermatologists should actively look for PsA manifestations in patients with psoriasis during each patient encounter [5]. Such routine screening is important because most patients with psoriatic disease present to dermatologists long before indications of joint involvement emerge $[11,22,28]$. Early treatment is vital for alleviating symptoms, preventing irreversible structural damage, and maximizing QoL [5, 10, 29-31]. Even a 6-month delay in PsA diagnosis can adversely affect radiographic and long-term functional outcomes [32].

This review provides an overview of the pathogenesis, clinical presentation, and treatment of enthesitis and dactylitis, as well as guidance for evaluation and treatment of psoriatic disease.

\section{Pathogenesis of Enthesitis and Dactylitis}

Entheses-sites of insertion of tendons, ligaments, fascia, or capsules to bone that are frequently subject to repeated biomechanical stress-are more than just focal attachments and may be important in PsA development [7, 33-35]. Entheses are anatomically, functionally, and physiologically associated with synovia, and form the 'enthesis organ' or 'synovio-entheseal complex,' which are comprised of soft (e.g. tendon, ligament, and associated fibrocartilage) and hard (e.g. calcified fibrocartilage, and adjacent bone and trabecular network) tissue (Fig. 2) [33-35]. The enthesis organ dissipates stress, which may be a potential triggering mechanism of enthesitis and, ultimately, PsA [33]. According to this theory, biomechanical stress at entheses in a genetically predisposed individual leads to production of cytokines, which enter synovial tissue, leading to an articular inflammatory response [34]. The 'enthesis organ' may also explain the high prevalence of nail psoriasis (80\%) in PsA as nails are functionally integrated with distal interphalangeal (DIP) joint entheses [7, 36-41]. Specifically, the extensor tendon, which is attached to the terminal phalanx, extends distally and connects with 
Table 1 CASPAR: PsA classification criteria. Reprinted with permission from Taylor et al. [12]

To meet the criteria for PsA classification, a patient must have inflammatory articular disease of the joint, spine, or entheses with $\geq 3$ points from the following five categories:

1 Evidence of current psoriasis, ${ }^{\text {a }}$ a personal history of psoriasis, or a family history of psoriasis

Current psoriasis

Personal history of psoriasis, which may be obtained from a patient, family physician, dermatologist, rheumatologist, or other qualified healthcare provider

Family history of psoriasis (i.e. first- or second-degree relative)

2 Typical psoriatic nail dystrophy, including onycholysis, pitting, and hyperkeratosis observed on current physical examination

3 A negative test result for the presence of rheumatoid factor by any method except latex, but preferably by enzyme-linked immuno- 1 sorbent assay or nephelometry, according to the local laboratory reference range

4 Current dactylitis or a history of dactylitis recorded by a rheumatologist

5 Radiographic evidence of juxta-articular new bone formation, appearing as ill-defined ossification near joint margins (but exclud- 1 ing osteophyte formation) on plain radiographs of the hand or foot

CASPAR classification criteria for psoriatic arthritis, PSA psoriatic arthritis

${ }^{a}$ Psoriatic skin or scalp disease present today, as judged by a rheumatologist or dermatologist

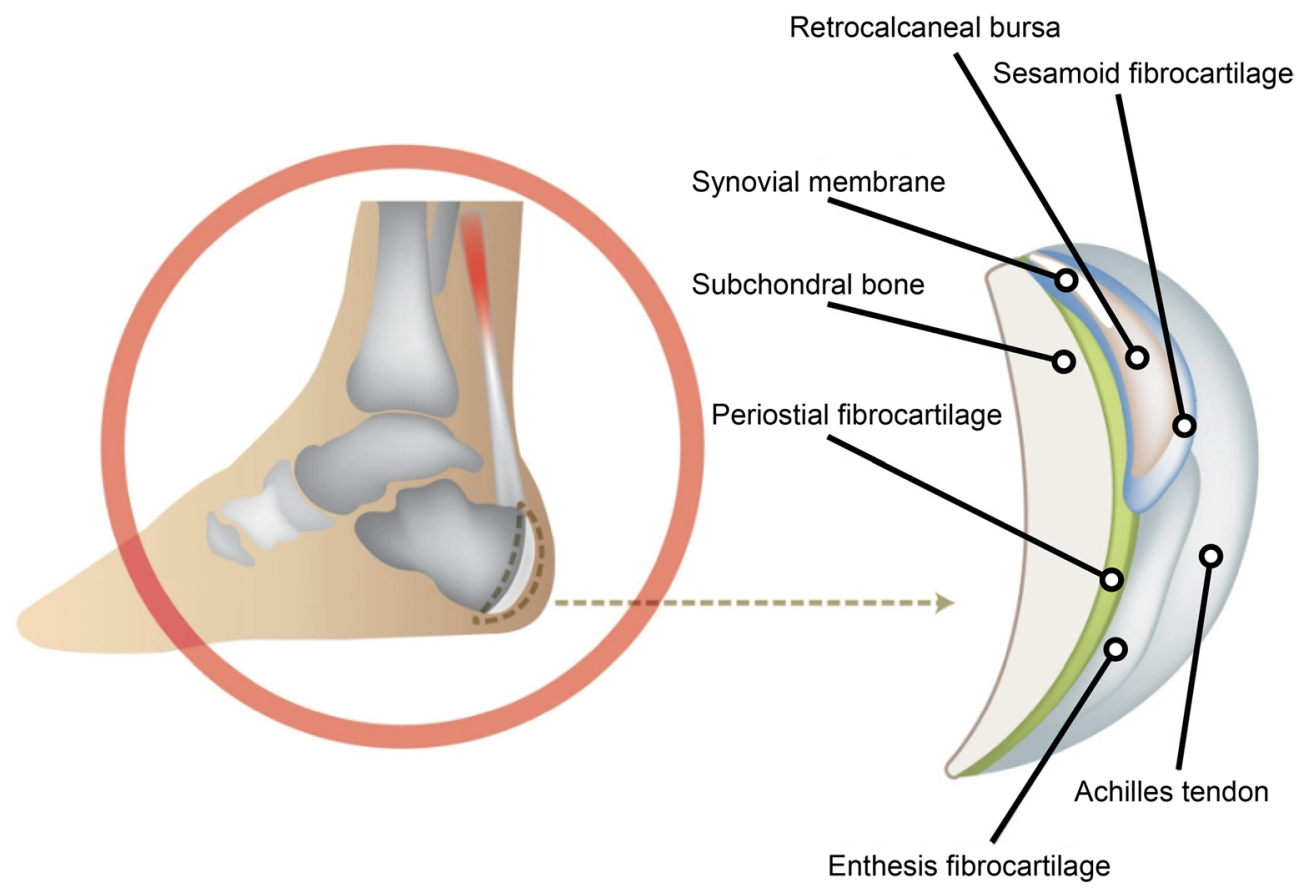

Fig. 2 The enthesis organ. Republished with permission from Kehl et al. [34]

the nail root, making nail fascia an extension of the enthesis (Fig. 3) [33, 42].

On a genetic/biomolecular level, enthesitis is associated with human leukocyte antigen (HLA) haplotype $\mathrm{B} * 27: 05-\mathrm{C} * 01: 02$ and its two constituent alleles $(\mathrm{B} * 27: 05$ and $\left.\mathrm{C}^{*} 01: 02\right)$, and studies have shown that HLA-B27 can misfold and promote increased production of interleukin (IL)-23 [34, 43]. Murine models have highlighted the importance of IL-23 in the development of enthesitis and PsA as IL-23 promotes entheseal inflammation through 


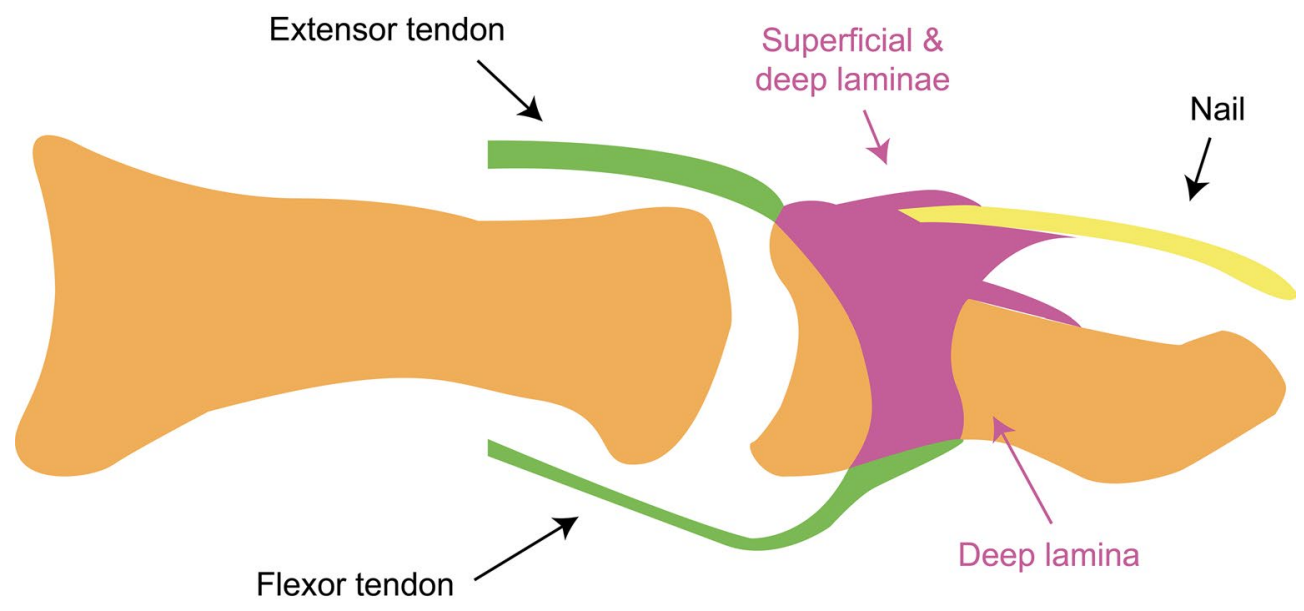

Fig. 3 Nails are functionally integrated with distal interphalangeal joint entheses. Republished with permission from McGonagle et al. [96]. Copyright () 2009 Karger Publishers, Basel, Switzerland

IL-23-responsive $\mathrm{CD}^{+} \mathrm{CD}^{-} \mathrm{CD} 8^{-}$resident lymphocytes in inflamed entheses [44]. Moreover, when IL-23 is exposed to murine entheseal tissue in culture, expression of important pathogenic genes, including $I L 17 a$, IL17f, IL22, and bone morphogenic protein 7, are upregulated [44]. Murine models of autoimmune inflammatory arthritis have also demonstrated the importance of the IL-23/IL-17 axis and IL-22 in enthesitis pathogenesis [45]. Additionally, in a murine model of chronic tumor necrosis factor (TNF)- $\alpha$ production, enthesitis was an early disease feature and was dependent on biomechanical strain [46].

The underlying pathology of dactylitis, (or pan-digital inflammation) is tenosynovitis and peritendinous soft tissue edema, enthesitis, and, less frequently, synovitis [7]. While the genetic/biomolecular pathogenesis of dactylitis is not well understood, dactylitis is known to be associated with the $\mathrm{B}^{*} 27: 05-\mathrm{C}^{*} 01: 02$ haplotype, in addition to the $\mathrm{B} * 08: 01-\mathrm{C} * 07: 01$ haplotype [43]. Furthermore, murine models support the role of TNF $\alpha$, IL-23, and IL-17A in dactylitis. Specifically, in one murine model, IL-23 induced paw swelling, and, in a second model, neutralizing IL-17A abrogated disease symptoms, including dactylitis [44, 47]. Another murine model with increased expression of TNF $\alpha$, IL-6, and Dickkopf-1 exhibited dactylitis [48].

Overall, the importance of TNF $\alpha$ and the IL-17/IL-23 axis in PsA, enthesitis, and dactylitis has been validated clinically with biologic agents that neutralize these cytokines. These agents are efficacious in treating PsA broadly, as well as enthesitis and dactylitis more specifically [49-58].
Fig. 4 Imaging of enthesitis and dactylitis. a X-ray image of enthesitis. L: Mineralized scar (enthesophyte, so-called 'lower spur') on the lower surface of the calcaneal tuberosity at the flexor digitorum brevis enthesis, erosions on the medial malleoli with concomitant ossification reactions. R: Erosion in the bony part of the Achilles tendon enthesis on the left side (republished with permission from Sudoł-Szopińska et al. [97]). b X-ray image of dactylitis. Radiograph of both hands showing fluffy periostitis in the proximal phalanges of all fingers bilaterally. A soft tissue swelling is seen around the middle finger of the left hand, suggestive of a 'sausage digit' (republished with permission from Balakrishnan and Madnani [98]). c MRI of Achilles enthesitis. L: Sagittal MRI fat-sat images showing retrocalcaneal bursitis (white solid arrow), diffuse bone marrow edema (arrowheads) at the insertion of the Achilles tendon and the insertion of the plantar fascia, soft tissue edema (black solid arrow), plantar fasciitis (open arrow), and irregularities of cortical bone at the Achilles tendon enthesis (star). R: Sagittal MRI fat-sat images depicting improvement of enthesitis in the same patient (republished with permission from Mancarella et al. [99]). d MRI of dactylitis showing the axial section at the midpoint of the proximal phalanx of the third finger of the right hand (dactylitis) and the contralateral digit (normal) for comparison. Intense signal from the synovial sheaths in the T2-weighted image of the digit with dactylitis is visible (arrowhead) (republished with permission from Olivieri et al. [100]). e US image of enthesitis. L: US image (longitudinal view with power Doppler) of enthesitis at the Achilles tendon before treatment. The retrocalcaneal (star) bursa is distended with anechoic effusion, and peribursal synovitis is observed. R: Repeated US image of the same enthesis demonstrating improvement of effusions and power Doppler signal after treatment (republished with permission from Batmaz et al. [101]). f US image of dactylitis. L: US image (transverse view) at the midpoint of the volar aspect (up) of the proximal right phalanx. An anechoic area around the flexor tendons (black arrow) is visible. R: US image (transverse view) of third left finger showing normal aspect of the flexor tendons (republished with permission from Olivieri et al. [100]). AT Achilles tendon, $C$ calcaneus, $D 1$ anteroposterior diameter of the synovial sheaths, $L$ left, $M R I$ magnetic resonance imaging, $R$ right, $U S$ ultrasound 
a
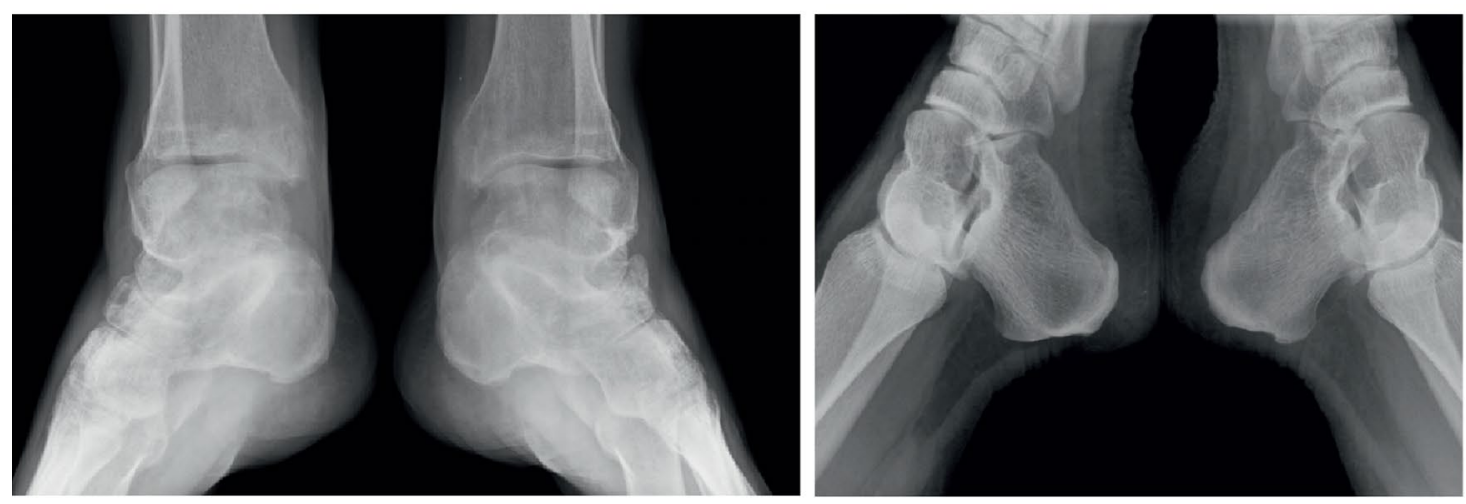

b

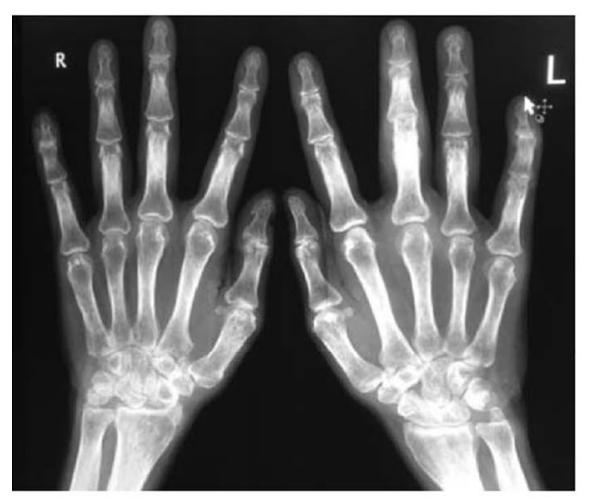

d

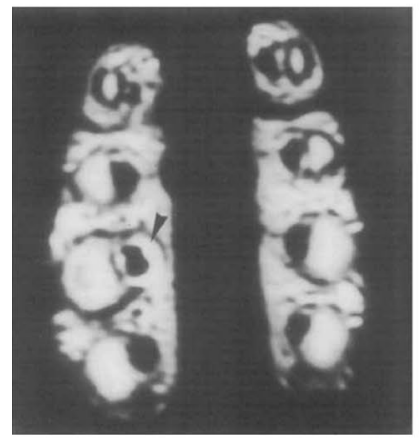

e
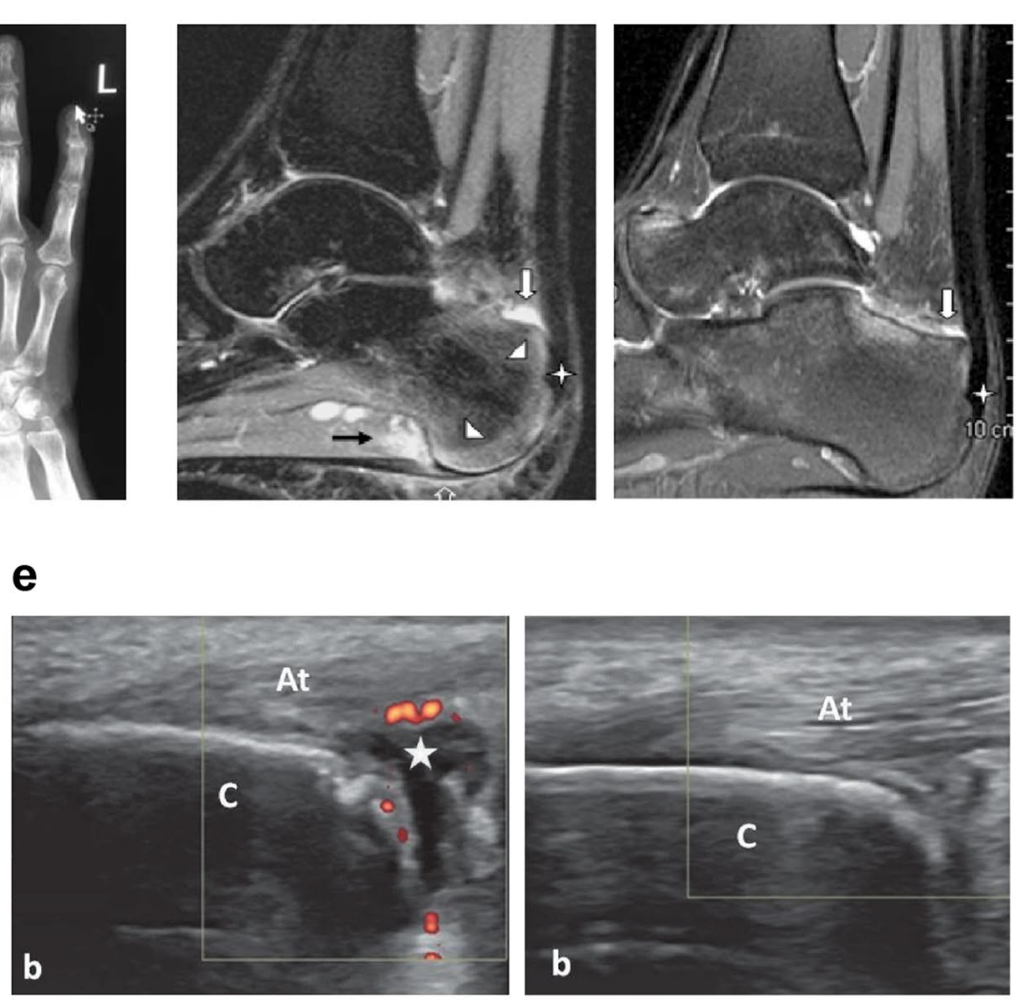

f
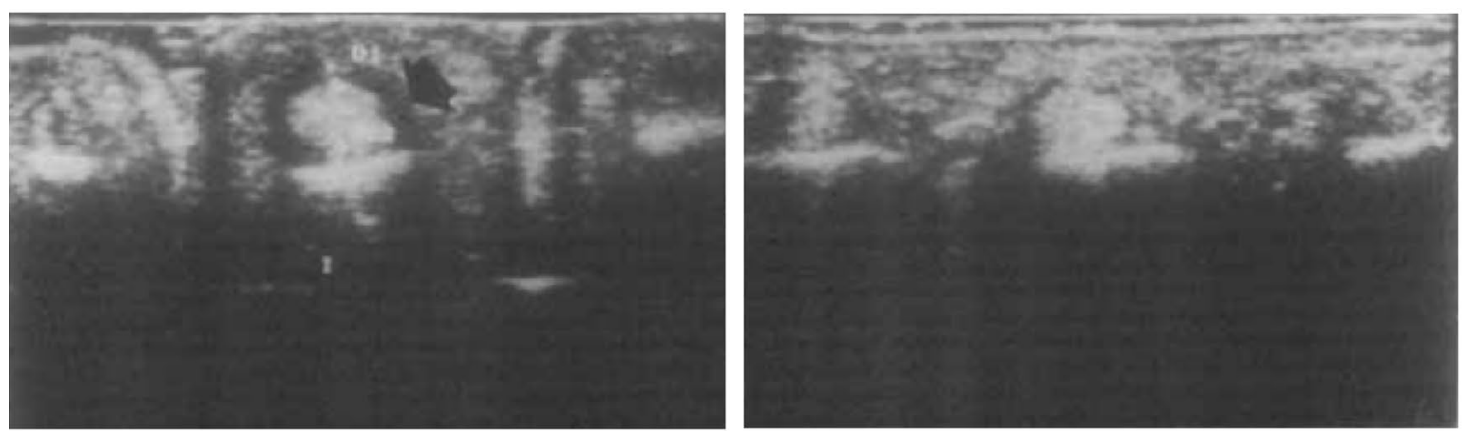


\section{Clinical Features of Enthesitis and Dactylitis}

Enthesitis often mimics symptoms associated with mechanical injury [7, 59]. Symptoms include tenderness/soreness/pain at entheses (which may be elicited via palpation) and potential visible signs, such as redness and swelling at insertion sites (Fig. 1a) [7]. The disease can occur at one or more sites simultaneously, and occurs more often in lower than upper extremities $[5,7,18]$. The plantar fascia and Achilles tendon insertion sites are commonly affected [5, 7, 18]. Enthesitis is frequently identified as the etiopathogenic site of inflammation in SpA in general, and PsA specifically [33-35].

In 1998, Rothschild et al. [24] defined dactylitis, or 'sausage-shaped digits,' as "uniform swelling such that the soft tissues between the metacarpophalangeal and proximal interphalangeal, proximal and DIP, and/or DIP and digital tuft are diffusely swollen to the extent that the actual joint swelling could no longer be independently recognized." Clinically, dactylitis is recognized by swelling of an entire digit that is different from adjacent digits (Fig. 1b) [35, 60, 61]. Swelling of the synovial sheaths often prevents flexion [60].

\section{Imaging of Enthesitis and Dactylitis}

Conventional radiography, ultrasound (US), and magnetic resonance imaging (MRI) are used to assess PsA and its manifestations, including enthesitis and dactylitis. However, each modality has advantages and disadvantages and is capable of imaging different tissues and abnormalities [34, 62, 63].

\subsection{Conventional Radiography}

Evidence of enthesitis by conventional radiography include bone cortex irregularities, erosions, entheseal soft tissue calcifications, and new bone formation, whereas signs of dactylitis include soft tissue swelling (Fig. 4a) $[35,63,64]$. Entheseal bone changes detected with conventional radiography appear relatively late in the disease process [63]. Furthermore, conventional radiography is not ideal for imaging the various tissue compartments affected in dactylitic digits, but can detect soft tissue swelling and underlying bone abnormalities (Fig. 4b) [65].

\subsection{Magnetic Resonance Imaging}

Enthesitis is visualized with MRI as soft tissue inflammatory changes outside the joint capsule, focal thickening, rounded configuration at the insertion site, loss of flattened hypointense appearance, and perientheseal bone marrow edema (Fig. 4c) [34, 66]. Features of dactylitis include synovitis, bone edema, soft tissue edema, and flexor tenosynovitis (Fig. 4d) [67]. Despite advantages over radiographs, detecting peripheral enthesitis and dactylitis can be challenging as the MRI signal can be low in areas of

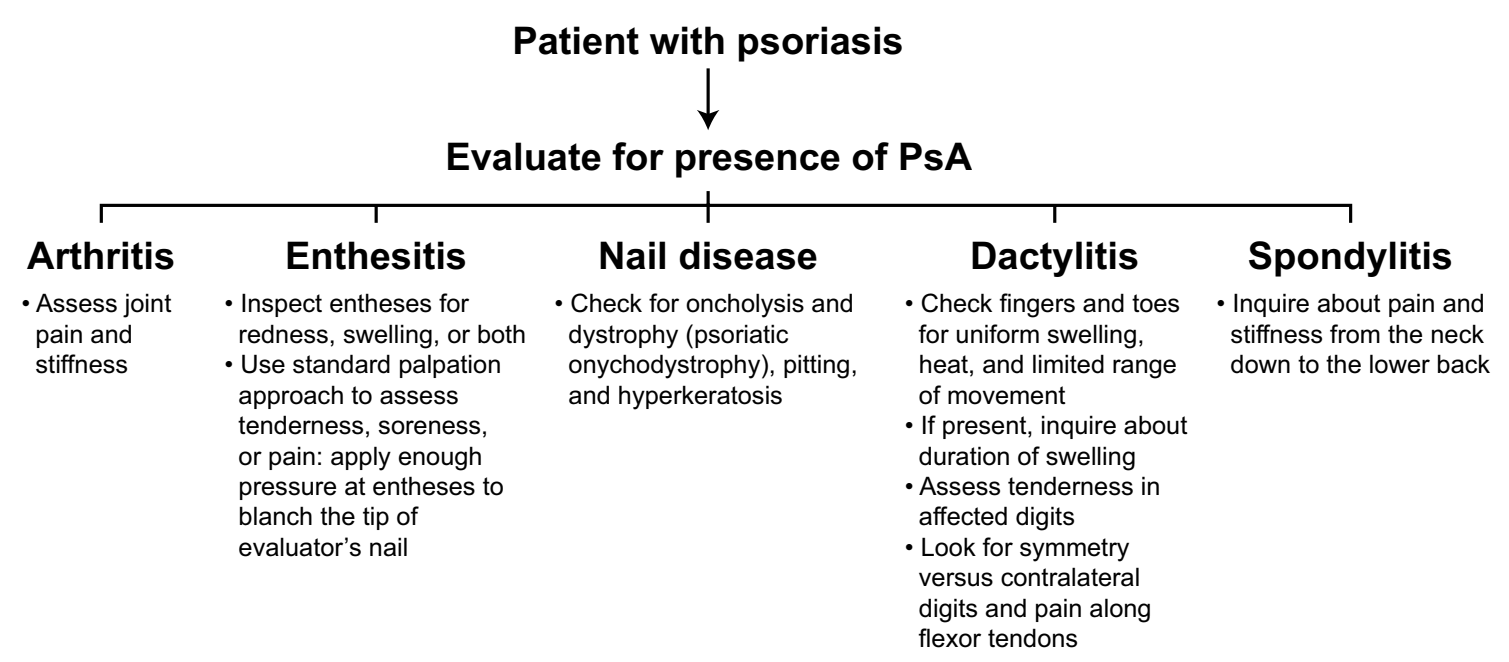

Example probing questions

- Have you previously experienced swelling of your fingers or toes?

- Do you have any red or hot joints?

- Do you have pain or tenderness in the soles of your feet or heels?

- Do you have pain or tenderness in your lower back, pelvis, or hip?

- Do you have morning stiffness in your joints that improves as the day progresses or with exercise?

Fig. 5 Evaluating patients with psoriasis for signs and symptoms of PsA. PsA psoriatic arthritis 
bone attachment (low water accumulation). Additionally, MRI is limited due to cost, availability, and the time taken to image each joint [68].

\subsection{Ultrasound Imaging}

In general, US is the preferred method to image enthesitis (Fig. 4e) [34, 63, 66]. In 2014, the Outcome Measures in Rheumatology (OMERACT) Ultrasound Task Force proposed hypoechogenicity, increased tendon insertion thickness, calcifications, enthesophytes, erosions, and Doppler activity as 'core elementary lesions' of USdetected enthesitis [69]. Key US components of dactylitis include soft tissue thickening, soft tissue edema, flexor tendon tenosynovitis, and joint synovitis (Fig. 4f) [62]. Disadvantages of US include screening large lower-limb entheses (because body mass index has a major impact on the entheseal findings at these locations), as well as the inability of US to image within bone [70-72]. Despite its shortcomings, US has several important advantages, including its ability to image tendons via a dynamic examination, and scan peripheral joints at varied angles [70, 73]. Additionally, US is considered a low-cost imaging procedure [73].

\section{Evaluation of Enthesitis and Dactylitis}

Because PsA onset typically follows that of psoriasis, dermatologists treating patients with psoriasis are in the unique position of detecting enthesitis and dactylitis early in the disease course [8, 28, 37, 39]. During each visit, patients with psoriasis should be evaluated for manifestations of PsA (Fig. 5). Comprehensive evaluation of the key clinical features of PsA (psoriasis, arthritis, enthesitis, dactylitis, and spondylitis), including assessment of severity of each feature and impact on physical function and QoL, is encouraged [49]. Patients may not understand the link between psoriasis and joint pain; therefore, specific probing questions are generally helpful (Fig. 5). Screening questionnaires, including the Psoriasis Epidemiology Screening Tool (PEST), Psoriatic Arthritis Screening and Evaluation (PASE) questionnaire, and Toronto Psoriatic Arthritis Screening (ToPAS) questionnaire, may be used to help dermatologists detect early signs and symptoms of Ps A [74-77].

Patients with PsA who have more actively inflamed joints, have higher body mass index, and are younger are at increased risk for enthesitis [18]. Enthesitis can be assessed by visually inspecting for swelling, and applying a standard palpation approach, in which tenderness, soreness, or pain can usually be elicited [7, 78]. However, while pain may be present because entheseal regions are highly innervated, visible signs of enthesitis are sometimes absent due to the avascular nature of entheses [79]. Diagnosing enthesitis can also be challenging because the characteristic symptoms of fibromyalgia (i.e. chronic widespread pain, particularly pain associated with tender points on digital palpation) overlap with those of SpA and enthesitis $[20,79,80]$. Although fibromyalgia is mostly a diagnosis of exclusion, certain features aid in discerning fibromyalgia from PsA [20,79]. Patients with fibromyalgia will have pain at non-entheseal sites and do not typically respond to biologic therapy [80].

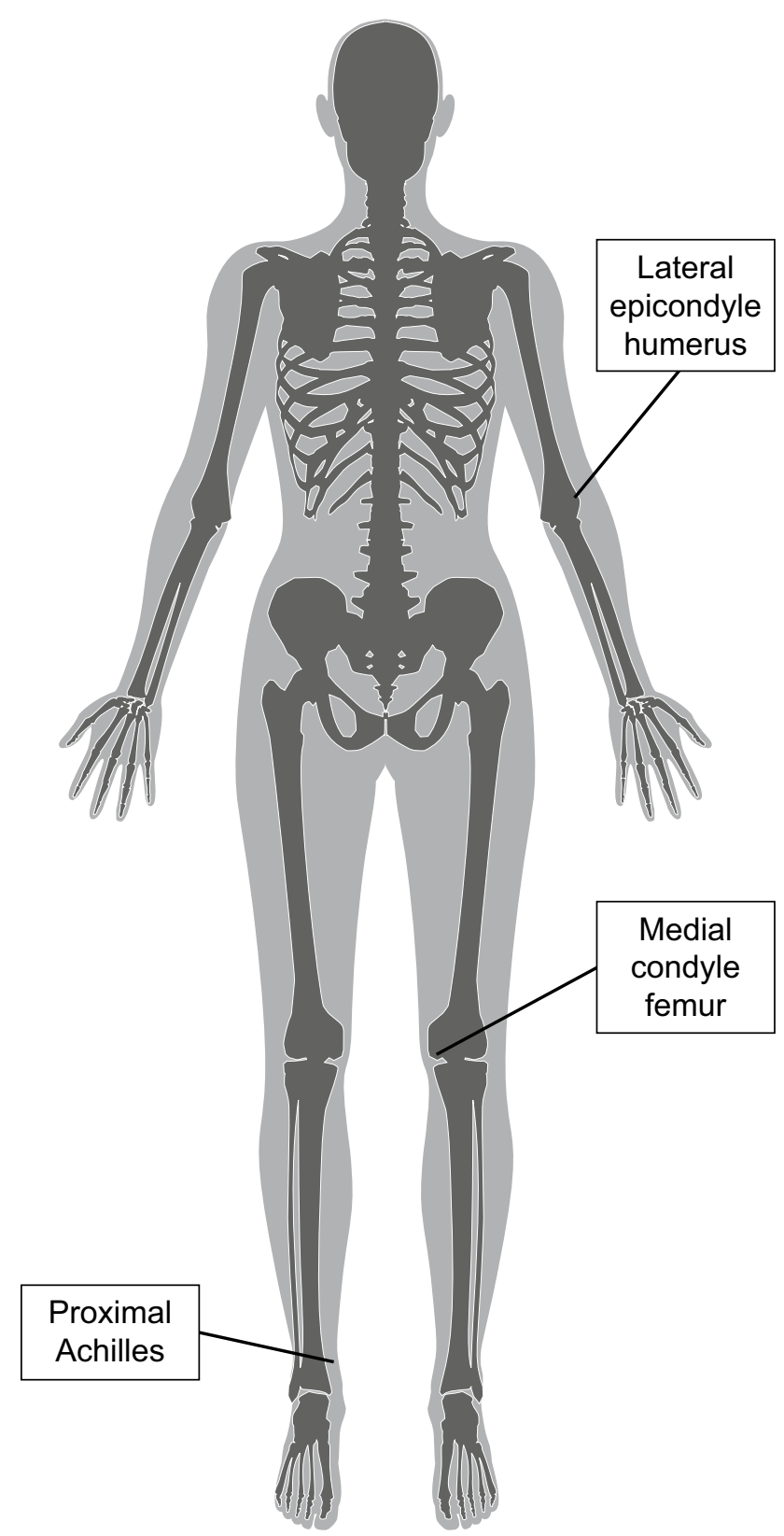

Fig. 6 Anatomical location of entheses assessed by the Leeds Enthesitis Index. Entheses are assessed bilaterally 
Dactylitis is clinically more apparent; however, diagnosis may be difficult in patients with early or mild disease [59]. Affected digits are usually noticeably swollen relative to other digits and may have limited range of motion [60]. Patients also tend to exhibit pain along the flexor tendons. In patients with PsA, dactylitis typically has asymmetrical digit presentation, predominates in feet, and often affects multiple digits [35, 60]. Onset can be acute (tender), meaning the digit is red, hot, and tender, or chronic (nontender), meaning the digit is swollen without the acute inflammatory changes or tenderness [35, 81]. Dactylitis is associated with erosive disease and radiologic progression [16].

In 2016, OMERACT updated the core set of domains for PsA to be assessed in clinical trials [82].

Table 2 Enthesitis outcomes in randomized controlled trials of PsA

\begin{tabular}{|c|c|c|c|}
\hline Drug class & Compound & Enthesitis measure & Efficacy at week 24 \\
\hline \multirow[t]{6}{*}{$\mathrm{TNF} \alpha$ inhibitor } & Adalimumab [53] & $\begin{array}{l}\text { 4-point (exploratory end- } \\
\text { point) }\end{array}$ & $\begin{array}{l}\text { Mean improvement in enthesitis from baseline } \\
\text { Improvement with adalimumab greater than placebo; statistical } \\
\text { significance was not reached (values not presented) }\end{array}$ \\
\hline & Infliximab [54] & $\begin{array}{l}\text { Presence/absence of } \\
\text { enthesopathy in the feet } \\
\text { (endpoint not specified) }\end{array}$ & $\begin{array}{l}\text { Percentage of patients with enthesopathy in the feet } \\
\text { Infliximab (20\%), placebo }(37 \%) ; p=0.002\end{array}$ \\
\hline & Golimumab [55] & $\begin{array}{l}\text { Modified MASES (explora- } \\
\text { tory endpoint) }\end{array}$ & $\begin{array}{l}\text { Median percentage change from baseline } \\
\text { Golimumab } 50 \mathrm{mg}(60 \%) \text {, golimumab } 100 \mathrm{mg}(67 \%) \text {, placebo }(12 \%) \text {; } \\
p<0.001 \text { vs. placebo for both }\end{array}$ \\
\hline & $\begin{array}{l}\text { Golimumab (intrave- } \\
\text { nous) [56] }\end{array}$ & $\begin{array}{l}\text { LEI (secondary endpoint at } \\
\text { week 14) }\end{array}$ & $\begin{array}{l}\text { Mean change from baseline } \\
\text { Golimumab } 2 \mathrm{mg} / \mathrm{kg}(-2.1) \text {, placebo }(-1.1) ; p<0.001\end{array}$ \\
\hline & Etanercept [57] & $\begin{array}{l}\text { 4-point (secondary end- } \\
\text { point) }\end{array}$ & $\begin{array}{l}\text { Percentage of patients with a reduction of enthesitis sites } \\
\text { Etanercept } 50 \mathrm{mg} \text { BIW/QW (80.9\%), etanercept } 50 \mathrm{mg} \text { QW/QW } \\
(81.3 \%)\end{array}$ \\
\hline & $\begin{array}{l}\text { Certolizumab pegol } \\
\text { [58] }\end{array}$ & LEI (secondary endpoint) & $\begin{array}{l}\text { Mean change from baseline } \\
\text { Certolizumab pegol } 200 \mathrm{mg}(-2.0) \text {, certolizumab pegol } 400 \mathrm{mg} \\
(-1.8) \text {, placebo }(-1.1) ; p<0.001 \text { vs. placebo and } p=0.003 \mathrm{vs} \text {. } \\
\text { placebo, respectively }\end{array}$ \\
\hline IL-12/23 inhibitor & Ustekinumab [102] & $\begin{array}{l}\text { Modified MASES (explora- } \\
\text { tory endpoint) }\end{array}$ & $\begin{array}{l}\text { Median percentage change from baseline } \\
\text { Ustekinumab } 45 \mathrm{mg} \text { (approximately }-45 \% ; p=0.0019 \text { vs. placebo) } \\
\text { and ustekinumab } 90 \mathrm{mg} \text { (approximately }-50 \% ; p<0.0001 \text { vs. } \\
\text { placebo) }\end{array}$ \\
\hline IL-23 inhibitor & Guselkumab $^{\mathrm{a}}$ [103] & LEI (secondary endpoint) & $\begin{array}{l}\text { Median percentage change from baseline } \\
\text { Guselkumab } 100 \mathrm{mg}(-100 \%) \text {, placebo }(-33 \%) ; p=0.009 \text { vs. } \\
\text { placebo }\end{array}$ \\
\hline \multirow[t]{2}{*}{ IL-17A inhibitor } & Ixekizumab [104] & LEI (secondary endpoint) & $\begin{array}{l}\text { Percentage of patients who achieved complete resolution of enthesitis } \\
\text { Ixekizumab Q4W (35\%), ixekizumab Q2W (31\%), placebo ( } 22 \%) \text {; } \\
p=0.08 \text { vs. placebo and } p=0.27 \text { vs. placebo, respectively }\end{array}$ \\
\hline & Secukinumab [105] & LEI (secondary endpoint) & $\begin{array}{l}\text { Percentage of patients who achieved complete resolution of enthesitis } \\
\text { Secukinumab } 300 \mathrm{mg}(48.2 \%) \text {, secukinumab } 150 \mathrm{mg}(42.2 \%) \text {, } \\
\text { placebo }(21.5 \%) ; p<0.01 \text { vs. placebo and } p<0.05 \text { vs. placebo, } \\
\text { respectively }\end{array}$ \\
\hline $\begin{array}{l}\text { Small-molecule } \\
\text { PDE4 inhibitor }\end{array}$ & Apremilast [106] & $\begin{array}{l}\text { MASES (secondary end- } \\
\text { point at week 16) }\end{array}$ & $\begin{array}{l}\text { Percentage of patients who achieved complete resolution of enthesitis } \\
\text { Apremilast } 20 \mathrm{mg}(32 \%) \text {, apremilast } 30 \mathrm{mg}(33.6 \%) \text {, placebo } \\
(14.4 \%) ; p=0.0037 \text { vs. placebo and } p=0.0013 \text { vs. placebo, } \\
\text { respectively }\end{array}$ \\
\hline T-cell inhibitor & Abatacept [89] & $\begin{array}{l}\text { LEI (prespecified explora- } \\
\text { tory endpoint) }\end{array}$ & $\begin{array}{l}\text { Percentage of patients achieving complete resolution of enthesitis } \\
\text { Abatacept (32.9\%), placebo (21.2\%); statistical significance was not } \\
\text { reached }\end{array}$ \\
\hline $\begin{array}{l}\text { Small-molecule } \\
\text { JAK inhibitor }\end{array}$ & Tofacitinib [90] & LEI (secondary endpoint) & $\begin{array}{l}\text { Mean change from baseline } \\
\text { Tofacitinib } 5 \mathrm{mg}(-1.5) \text {, tofacitinib } 10 \mathrm{mg}(-1.6)\end{array}$ \\
\hline
\end{tabular}

Efficacy results are presented at week 24 for consistency, and studies with secondary endpoints at other timepoints are indicated in the 'Enthesitis measure' column. All agents are approved for PsA unless otherwise noted. The score range for LEI, MASES, and modified MASES is 0-6, $0-13$, and $0-15$, respectively

$B I W$ twice weekly, IL interleukin, JAK Janus kinase, LEI Leeds Enthesitis Index, MASES Maastricht Ankylosing Spondylitis Enthesitis Score, $P D E 4$ phosphodiesterase-4, $P S A$ psoriatic arthritis, $Q W$ once weekly, $Q 4 W$ every 4 weeks, $Q 2 W$ every 2 weeks, $T N F$ tumor necrosis factor ${ }^{a}$ Experimental compound in PsA, approved for moderate-to-severe psoriasis 
Table 3 Dactylitis outcomes in randomized controlled trials of PsA

\begin{tabular}{|c|c|c|c|}
\hline Drug class & Compound & Dactylitis measure & Efficacy at week 24 \\
\hline \multirow[t]{6}{*}{ TNF $\alpha$ inhibitor } & Adalimumab [53] & $\begin{array}{l}\text { Scale of } 0-3 \text { for each } \\
\text { digit of hands and } \\
\text { feet (exploratory } \\
\text { endpoint) }\end{array}$ & $\begin{array}{l}\text { Mean improvement in dactylitis from baseline } \\
\text { Improvement with adalimumab greater than placebo; statistical } \\
\text { significance was not reached (values not presented) }\end{array}$ \\
\hline & Infliximab [54] & $\begin{array}{l}\text { Presence/absence of } \\
\text { dactylitis (endpoint } \\
\text { not specified) }\end{array}$ & $\begin{array}{l}\text { Percentage of patients with dactylitis } \\
\text { Infliximab (12\%), placebo }(34 \%) ; p<0.001\end{array}$ \\
\hline & Golimumab [55] & $\begin{array}{l}\text { Scale of } 0-3 \text { for each } \\
\text { digit of hands and } \\
\text { feet (exploratory } \\
\text { endpoint) }\end{array}$ & $\begin{array}{l}\text { Median percentage change from baseline } \\
\text { Golimumab } 50 \mathrm{mg}(100 \%) \text {, golimumab } 100 \mathrm{mg}(100 \%) \text {, placebo } \\
(42 \%) ; p=0.09 \text { vs. placebo and } p<0.001 \text { vs. placebo, respectively }\end{array}$ \\
\hline & $\begin{array}{l}\text { Golimumab (intravenous) } \\
\text { [56] }\end{array}$ & $\begin{array}{l}\text { Scale of } 0-3 \text { for each } \\
\text { digit of hands and } \\
\text { feet (secondary end- } \\
\text { point at week 14) }\end{array}$ & $\begin{array}{l}\text { Mean change from baseline } \\
\text { Golimumab } 2 \mathrm{mg} / \mathrm{kg}(-8.2) \text {, placebo }(-5.0) ; p<0.001\end{array}$ \\
\hline & Etanercept [57] & $\begin{array}{l}\text { Scale of } 0-3 \text { for each } \\
\text { digit of hands and } \\
\text { feet (secondary } \\
\text { endpoint) }\end{array}$ & $\begin{array}{l}\text { Mean percentage change from baseline } \\
\text { Etanercept } 50 \mathrm{mg} \text { BIW/QW (84.5\%), etanercept } 50 \mathrm{mg} \text { QW/QW } \\
(84.8 \%)\end{array}$ \\
\hline & Certolizumab pegol [58] & $\begin{array}{l}\text { LDI (secondary end- } \\
\text { point) }\end{array}$ & $\begin{array}{l}\text { Mean change from baseline } \\
\text { Certolizumab pegol } 200 \mathrm{mg}(-40.7) \text {, certolizumab pegol } 400 \mathrm{mg} \\
(-53.5) \text {, placebo }(-22.0) ; p=0.002 \text { vs. placebo and } p<0.001 \text { vs. } \\
\text { placebo, respectively }\end{array}$ \\
\hline IL-12/23 inhibitor & Ustekinumab [102] & $\begin{array}{l}\text { Scale of } 0-3 \text { for each } \\
\text { digit of hands and } \\
\text { feet (exploratory } \\
\text { endpoint) }\end{array}$ & $\begin{array}{l}\text { Median percentage change from baseline } \\
\text { Ustekinumab } 45 \mathrm{mg} \text { (approximately }-75 \% ; p=0.0003 \text { vs. placebo) } \\
\text { and ustekinumab } 90 \mathrm{mg} \text { (approximately }-70 \% ; p=0.0003 \text { vs. } \\
\text { placebo) }\end{array}$ \\
\hline IL-23 inhibitor & Guselkumab $^{\mathrm{a}}$ [103] & $\begin{array}{l}\text { Scale of } 0-3 \text { for each } \\
\text { digit of hands and } \\
\text { feet (secondary } \\
\text { endpoint) }\end{array}$ & $\begin{array}{l}\text { Median percentage change from baseline } \\
\text { Guselkumab }(-100 \%) \text {, placebo }(-33 \%) ; p<0.001 \text { vs. placebo }\end{array}$ \\
\hline \multirow[t]{2}{*}{ IL-17A inhibitor } & Ixekizumab [104] & $\begin{array}{l}\text { LDI (secondary end- } \\
\text { point) }\end{array}$ & $\begin{array}{l}\text { Percentage of patients who achieved complete resolution of dactylitis } \\
\text { Ixekizumab Q4W (75\%), ixekizumab Q2W (50\%), placebo (21\%); } \\
p=0.002 \text { vs. placebo and } p=0.06 \text { vs. placebo, respectively }\end{array}$ \\
\hline & Secukinumab [105] & $\begin{array}{l}\text { Scale of } 1 \text { (presence) } \\
\text { or } 0 \text { (absence) for } \\
\text { each digit of hands } \\
\text { and feet (secondary } \\
\text { endpoint) }\end{array}$ & $\begin{array}{l}\text { Percentage of patients who achieved complete resolution of dactylitis } \\
\text { Secukinumab } 300 \mathrm{mg}(56.5 \%) \text {, secukinumab } 150 \mathrm{mg}(50.0 \%) \text {, pla- } \\
\text { cebo }(14.8 \%) ; p=0.0021 \text { vs. placebo and } p=0.0056 \text { vs. placebo, } \\
\text { respectively }\end{array}$ \\
\hline $\begin{array}{l}\text { Small-molecule } \\
\text { PDE4 inhibitor }\end{array}$ & Apremilast [106] & $\begin{array}{l}\text { Scale of } 1 \text { (presence) } \\
\text { or } 0 \text { (absence) for } \\
\text { each digit of hands } \\
\text { and feet (secondary } \\
\text { endpoint at week 16) }\end{array}$ & $\begin{array}{l}\text { Percentage of patients achieving complete resolution of dactylitis } \\
\text { Apremilast } 20 \mathrm{mg}(50.9 \%) \text {, apremilast } 30 \mathrm{mg}(47.7 \%) \text {, placebo } \\
\text { (40.9\%); statistical significance was not reached }\end{array}$ \\
\hline T-cell inhibitor & Abatacept [89] & $\begin{array}{l}\text { LDI (prespecified } \\
\text { exploratory endpoint) }\end{array}$ & $\begin{array}{l}\text { Percentage of patients achieving complete resolution of dactylitis } \\
\text { Abatacept (44.3\%), placebo (34.0\%); statistical significance was not } \\
\text { reached }\end{array}$ \\
\hline $\begin{array}{l}\text { Small-molecule } \\
\text { JAK inhibitor }\end{array}$ & Tofacitinib [90] & $\begin{array}{l}\text { Dactylitis severity } \\
\text { score (secondary } \\
\text { endpoint) }\end{array}$ & $\begin{array}{l}\text { Mean change from baseline } \\
\text { Tofacitinib } 5 \mathrm{mg}(-6.0) \text {, tofacitinib } 10 \mathrm{mg}(-6.0)\end{array}$ \\
\hline
\end{tabular}

Efficacy results are presented at week 24 for consistency, and studies with secondary endpoints at other timepoints are indicated in the 'Dactylitis measure' column. All agents are approved for PsA unless otherwise noted. The score range for the dactylitis severity score is 0-20. LDI is determined by the number of tender and swollen digits with a circumference $\geq 10 \%$ higher than the contralateral digit according to the LDI basic score

$B I W$ twice weekly, $I L$ interleukin, JAK Janus kinase, $L D I$ Leeds Dactylitis Index, PDE4 phosphodiesterase-4, PsA psoriatic arthritis, $Q W$ once weekly, $Q 4 W$ every 4 weeks, $Q 2 W$ every 2 weeks, $T N F$ tumor necrosis factor

${ }^{a}$ Experimental compound in PsA, approved for moderate-to-severe psoriasis 
Musculoskeletal disease activity, including enthesitis, dactylitis, and peripheral joint and spine symptoms, is the first domain, followed by skin activity, fatigue, systemic inflammation, and other measures (i.e. participation in work/social activities, structural damage, and economic cost). Several clinical indices exist for assessment of enthesitis, although only the Leeds Enthesitis Index (LEI) was specifically developed and validated in PsA [83]. For the Maastricht Ankylosing Spondylitis Enthesitis Score (MASES), 13 sites of enthesitis are assessed using a score of 0-13 [84]. For the Spondyloarthritis Research Consortium of Canada (SPARCC) score, 16 sites that were selected based on the most frequent enthesitis sites from Doppler US and MRI studies are assessed using a score of $0-16$ [85]. For LEI, tenderness at six sites is evaluated and scored as 0 (nontender) or 1 (tender) [Fig. 6] [61]. Formal training on these scoring systems improves accuracy and is recommended before use in clinical practice [78].

Clinical assessment complemented with imaging can optimally diagnose enthesitis. Few validated tools are available for assessing dactylitis; however, various measures (e.g. Clegg [tender and nontender digits], as well as number and severity of affected digits and tender digits) have been used in clinical trials $[83,86]$. The Leeds Dactylitis Index (LDI) is a more objective measure that, using assessment and a dactylometer, evaluates tenderness and digit circumference between dactylitic and contralateral nonaffected digits [61]. A composite measure, the Composite Psoriatic Disease Activity Index (CPDAI), which includes evaluation of joints, skin, enthesitis, dactylitis, and spinal manifestations in PsA, has also been developed [87].

\section{Treatment of Enthesitis and Dactylitis}

While PsA treatment guidelines from the Group for Research and Assessment of Psoriasis and Psoriatic Arthritis (GRAPPA) [49] and the European League Against Rheumatism (EULAR) [50] differ from each other in some respects, several points are alike. Common treatment goals are to achieve the lowest possible disease activity across domains; optimize functional status, QoL, and well-being; and prevent structural damage $[49,50]$. Additionally, because inflammation impacts long-term joint outcomes, its absence, as well as that of enthesitis and dactylitis, is important [50]. Treatment is also important so that disease-related complications can be avoided or minimized [50]. Because PsA is a heterogeneous disease, treatment decisions should be based on the specific domains affected $[49,50]$. Nonsteroidal anti-inflammatory drugs and corticosteroid injections are among the first-line treatments for enthesitis and dactylitis. Additionally, for patients with dactylitis or predominately entheseal manifestations of PsA, early use of agents targeting TNF $\alpha$ (adalimumab, certolizumab pegol, etanercept, infliximab, and golimumab), IL-12/23 (ustekinumab), IL-17A (secukinumab), or phosphodiesterase-4 (apremilast) is recommended by GRAPPA and EULAR in their respective guidelines [49, 50]. Ixekizumab (which targets IL-17A), abatacept (a T-cell inhibitor), and tofacitinib (a Janus kinase inhibitor) were approved for PsA after publication of these guidelines [88-90]. These agents have demonstrated efficacy for enthesitis and dactylitis (Tables 2 and 3).

\section{Conclusions}

Enthesitis and dactylitis are hallmarks of PsA. Although they can be challenging to detect, their identification is important for proper diagnosis and management of PsA. PsA with enthesitis and/or dactylitis results in greater disease activity and overall disease burden, poorer functional status, more pain and fatigue, and greater disability than PsA without these features [3, 91, 92]. Enthesitis severity is associated with radiographic peripheral and axial joint damage, and acute dactylitis is associated with greater radiographic damage [16, 93].

Radiographic progression in early PsA (less than or equal to 2 years from diagnosis) is substantial [94], and a delay in treatment initiation may result in irreversible joint damage, with subsequent limitations in daily activities, increased disability, and reduced QoL [32]. To minimize the risk of irreversible joint damage and functional limitation, patients with psoriasis should be closely monitored for these two early manifestations of PsA (enthesitis and dactylitis), and receive proper treatment.

Dermatologists can play a key role in the early identification of PsA in psoriasis. Through recognition of early disease manifestations such as enthesitis and dactylitis, dermatologists can initiate treatment with therapies that inhibit radiographic progression, and then refer patients to rheumatologists for collaborative care.

\section{Compliance with Ethical Standards}

Funding Technical assistance with editing, figure preparation, and styling of the manuscript for submission was provided by Oxford PharmaGenesis, Inc., and was funded by Novartis Pharmaceuticals Corporation. The authors were fully responsible for all content and editorial decisions and received no financial support or other form of compensation related to the development of this manuscript.

Conflict of interest Jerry Bagel has served as an investigator and consultant for AbbVie, Amgen, Boehringer Ingelheim, Sun, Janssen, Leo, Novartis, Celgene, and Eli Lilly; served as a consultant and speaker for Valiant; and served on the speaker's bureau for AbbVie, Eli Lilly, Janssen, Leo, and Novartis. Sergio Schwartzman has served as a con- 
sultant for AbbVie, Dermtech, Janssen, Eli Lilly, Myriad, Novartis, Pfizer, Sanofi, Regeneron, and UCB, and has served on the speakers' bureaus for AbbVie, Janssen, Eli Lilly, Novartis, Pfizer, Sanofi, Regeneron, and UCB.

Open Access This article is distributed under the terms of the Creative Commons Attribution-NonCommercial 4.0 International License (http://creativecommons.org/licenses/by-nc/4.0/), which permits any noncommercial use, distribution, and reproduction in any medium, provided you give appropriate credit to the original author(s) and the source, provide a link to the Creative Commons license, and indicate if changes were made.

\section{Glossary}

Dactylitis, or 'sausage digit': Uniform swelling such that the soft tissues between the metacarpophalangeal and proximal interphalangeal, proximal and distal interphalangeal, and/or distal interphalangeal joint and digital tuft are diffusely swollen to the extent that the actual joint swelling could no longer be independently recognized.

Enthesis (pl: entheses): Anatomic location where tendon, ligament, fascia, or joint capsule fibers insert into the bone.

Enthesitis: Inflammation of entheses.

Enthesopathy: Entheses involvement in any pathologic process (e.g. metabolic, inflammatory, traumatic or degenerative).

Oligoarticular: Affecting less than five joints.

Paresthesia: Abnormal sensation such as tingling, tickling, pricking, numbness, or burning of a person's skin with no apparent physical cause.

Periostitis: Inflammation of the periosteum, a layer of connective tissue that surrounds bone.

Peripheral arthritis: Arthritis of large or small joints (e.g. hips, knees, ankles, feet, elbows, wrists, and hands).

Polyarticular: Affecting five or more joints.

Spondyloarthropathy: Family of chronic diseases of joints that include ankylosing spondylitis, Reiter's syndrome (reactive arthritis), psoriatic arthritis, and joint problems linked to inflammatory bowel disease (enteropathic arthritis). Differs from other types of arthritis because it involves entheses.

Spondylitis: Inflammation of one or more vertebrae of the spine, sacroiliitis, facet arthritis, enthesitis of intervertebral ligaments, and osteitis.

Tenosynovitis: Inflammation of the lining of the sheath that surrounds a tendon.

\section{References}

1. Mease PJ, Gladman DD, Papp KA, Khraishi MM, Thaci D, Behrens F, et al. Prevalence of rheumatologist-diagnosed psoriatic arthritis in patients with psoriasis in European/
North American dermatology clinics. J Am Acad Dermatol. 2013;69:729-35.

2. Lebwohl MG, Kavanaugh A, Armstrong AW, Van Voorhees AS. US perspectives in the management of psoriasis and psoriatic arthritis: patient and physician results from the population-based Multinational Assessment of Psoriasis and Psoriatic Arthritis (MAPP) Survey. Am J Clin Dermatol. 2016;17:87-97.

3. Kavanaugh A, Helliwell P, Ritchlin CT. Psoriatic arthritis and burden of disease: patient perspectives from the population-based Multinational Assessment of Psoriasis and Psoriatic Arthritis (MAPP) Survey. Rheumatol Ther. 2016;3:91-102.

4. Eder L, Polachek A, Rosen CF, Chandran V, Cook R, Gladman DD. The development of psoriatic arthritis in patients with psoriasis is preceded by a period of nonspecific musculoskeletal symptoms: a prospective cohort study. Arthritis Rheumatol. 2017;69:622-9.

5. Gottlieb A, Korman NJ, Gordon KB, Feldman SR, Lebwohl M, Koo JY, et al. Guidelines of care for the management of psoriasis and psoriatic arthritis: section 2. Psoriatic arthritis: overview and guidelines of care for treatment with an emphasis on the biologics. J Am Acad Dermatol. 2008;58:851-64.

6. Ritchlin CT, Colbert RA, Gladman DD. Psoriatic arthritis. N Engl J Med. 2017;376:957-70.

7. Sakkas LI, Alexiou I, Simopoulou T, Vlychou M. Enthesitis in psoriatic arthritis. Semin Arthritis Rheum. 2013;43:325-34.

8. Gottlieb AB, Mease PJ, Mark Jackson J, Eisen D, Amy Xia H, Asare C, et al. Clinical characteristics of psoriatic arthritis and psoriasis in dermatologists' offices. J Dermatol Treat. 2006;17:279-87.

9. Gladman DD, Antoni C, Mease P, Clegg DO, Nash P. Psoriatic arthritis: epidemiology, clinical features, course, and outcome. Ann Rheum Dis. 2005;64(Suppl 2):ii14-7.

10. Gladman DD, Thavaneswaran A, Chandran V, Cook RJ. Do patients with psoriatic arthritis who present early fare better than those presenting later in the disease? Ann Rheum Dis. 2011;70:2152-4.

11. Pereira IA, Neves FS, Castro GRW. Extra-articular manifestations in spondyloarthritis are common and should be screened. Rheumatol Curr Res. 2012;2:111.

12. Taylor W, Gladman D, Helliwell P, Marchesoni A, Mease P, Mielants $\mathrm{H}$, et al. Classification criteria for psoriatic arthritis: development of new criteria from a large international study. Arthritis Rheum. 2006;54:2665-73.

13. Strand V, Sharp V, Koenig AS, Park G, Shi Y, Wang B, et al. Comparison of health-related quality of life in rheumatoid arthritis, psoriatic arthritis and psoriasis and effects of etanercept treatment. Ann Rheum Dis. 2012;71:1143-50.

14. Armstrong AW, Schupp C, Wu J, Bebo B. Quality of life and work productivity impairment among psoriasis patients: findings from the National Psoriasis Foundation survey data 2003-2011. PLoS One. 2012;7:e52935.

15. Singh JA, Strand V. Spondyloarthritis is associated with poor function and physical health-related quality of life. J Rheumatol. 2009;36:1012-20.

16. Brockbank JE, Stein M, Schentag CT, Gladman DD. Dactylitis in psoriatic arthritis: a marker for disease severity? Ann Rheum Dis. 2005;64:188-90.

17. Gladman DD, Ziouzina O, Thavaneswaran A, Chandran V. Dactylitis in psoriatic arthritis: prevalence and response to therapy in the biologic era. J Rheumatol. 2013;40:1357-9.

18. Polachek A, Li S, Chandran V, Gladman DD. Clinical enthesitis in a prospective longitudinal psoriatic arthritis cohort: incidence, prevalence, characteristics, and outcome. Arthritis Care Res (Hoboken). 2017;69:1685-91.

19. Salvarani C, Cantini F, Olivieri I, Macchioni P, Niccoli L, Padula $\mathrm{A}$, et al. Isolated peripheral enthesitis and/or dactylitis: a subset of psoriatic arthritis. J Rheumatol. 1997;24:1106-10. 
20. Marchesoni A, Atzeni F, Spadaro A, Lubrano E, Provenzano G, Cauli A, et al. Identification of the clinical features distinguishing psoriatic arthritis and fibromyalgia. J Rheumatol. 2012;39:849-55.

21. Marzo-Ortega H, Tanner SF, Rhodes LA, Tan AL, Conaghan PG, Hensor EM, et al. Magnetic resonance imaging in the assessment of metacarpophalangeal joint disease in early psoriatic and rheumatoid arthritis. Scand J Rheumatol. 2009;38:79-83.

22. Mease PJ, Armstrong AW. Managing patients with psoriatic disease: the diagnosis and pharmacologic treatment of psoriatic arthritis in patients with psoriasis. Drugs. 2014;74:423-41.

23. Fournié B, Crognier L, Arnaud C, Zabraniecki L, Lascaux-Lefebvre V, Marc V, et al. Proposed classification criteria of psoriatic arthritis. A preliminary study in 260 patients. Rev Rhum Engl Ed. 1999;66:446-56.

24. Rothschild BM, Pingitore C, Eaton M. Dactylitis: implications for clinical practice. Semin Arthritis Rheum. 1998;28:41-7.

25. Olivieri I, Scarano E, Padula A, Giasi V, Priolo F. Dactylitis, a term for different digit diseases. Scand J Rheumatol. 2006;35:333-40.

26. Frediani B, Falsetti P, Storri L, Allegri A, Bisogno S, Baldi F, et al. Ultrasound and clinical evaluation of quadricipital tendon enthesitis in patients with psoriatic arthritis and rheumatoid arthritis. Clin Rheumatol. 2002;21:203-6.

27. van de Kerkhof PC, Reich K, Kavanaugh A, Bachelez H, Barker J, Girolomoni G, et al. Physician perspectives in the management of psoriasis and psoriatic arthritis: results from the population-based Multinational Assessment of Psoriasis and Psoriatic Arthritis survey. J Eur Acad Dermatol Venereol. 2015;29:2002-10.

28. Yamamoto T. Optimal management of dactylitis in patients with psoriatic arthritis. Open Access Rheumatol. 2015;7:55-62.

29. McLaughlin M, Östör A. Early treatment of psoriatic arthritis improves prognosis. Practitioner. 2014;258(21-4):3.

30. Kirkham B, de Vlam K, Li W, Boggs R, Mallbris L, Nab HW, et al. Early treatment of psoriatic arthritis is associated with improved patient-reported outcomes: findings from the etanercept PRESTA trial. Clin Exp Rheumatol. 2015;33:11-9.

31. Gladman DD. Recent advances in understanding and managing psoriatic arthritis. F1000Research. 2016;5:2670.

32. Haroon M, Gallagher P, FitzGerald O. Diagnostic delay of more than 6 months contributes to poor radiographic and functional outcome in psoriatic arthritis. Ann Rheum Dis. 2015;74:1045-50.

33. McGonagle D. Enthesitis: an autoinflammatory lesion linking nail and joint involvement in psoriatic disease. J Eur Acad Dermatol Venereol. 2009;23(Suppl 1):9-13.

34. Kehl AS, Corr M, Weisman MH. Enthesitis: new insights into pathogenesis, diagnostic modalities, and treatment. Arthritis Rheumatol. 2016;68:312-22.

35. Siegel EL, Orbai AM, Ritchlin CT. Targeting extra-articular manifestations in PsA: a closer look at enthesitis and dactylitis. Curr Opin Rheumatol. 2015;27:111-7.

36. Williamson L, Dalbeth N, Dockerty JL, Gee BC, Weatherall $\mathrm{R}$, Wordsworth BP. Extended report: nail disease in psoriatic arthritis-clinically important, potentially treatable and often overlooked. Rheumatology (Oxf). 2004;43:790-4.

37. Ash ZR, Tinazzi I, Gallego CC, Kwok C, Wilson C, Goodfield $\mathrm{M}$, et al. Psoriasis patients with nail disease have a greater magnitude of underlying systemic subclinical enthesopathy than those with normal nails. Ann Rheum Dis. 2012;71:553-6.

38. Aydin SZ, Castillo-Gallego C, Ash ZR, Marzo-Ortega H, Emery $\mathrm{P}$, Wakefield RJ, et al. Ultrasonographic assessment of nail in psoriatic disease shows a link between onychopathy and distal interphalangeal joint extensor tendon enthesopathy. Dermatology. 2012;225:231-5.
39. Raposo I, Torres T. Nail psoriasis as a predictor of the development of psoriatic arthritis. Actas Dermosifiliogr. 2015;106:452-7.

40. Cunha JS, Qureshi AA, Reginato AM. Nail enthesis ultrasound in psoriasis and psoriatic arthritis: a report from the 2016 GRAPPA Annual Meeting. J Rheumatol. 2017;44:688-90.

41. Acosta-Felquer ML, Ruta S, Rosa J, Marin J, Ferreyra-Garrot L, Galimberti ML, et al. Ultrasound entheseal abnormalities at the distal interphalangeal joints and clinical nail involvement in patients with psoriasis and psoriatic arthritis, supporting the nail-enthesitis theory. Semin Arthritis Rheum. 2017;47:338-42.

42. Tan AL, Benjamin M, Toumi H, Grainger AJ, Tanner SF, Emery $\mathrm{P}$, et al. The relationship between the extensor tendon enthesis and the nail in distal interphalangeal joint disease in psoriatic arthritis - a high-resolution MRI and histological study. Rheumatology (Oxf). 2007;46:253-6.

43. FitzGerald O, Haroon M, Giles JT, Winchester R. Concepts of pathogenesis in psoriatic arthritis: genotype determines clinical phenotype. Arthritis Res Ther. 2015;17:115.

44. Sherlock JP, Joyce-Shaikh B, Turner SP, Chao CC, Sathe M, Grein J, et al. IL-23 induces spondyloarthropathy by acting on ROR- $\gamma \mathrm{t}^{+} \mathrm{CD}^{+}{ }^{+} \mathrm{CD} 4^{-} \mathrm{CD} 8^{-}$entheseal resident $\mathrm{T}$ cells. Nat Med. 2012;18:1069-76.

45. Benham H, Rehaume LM, Hasnain SZ, Velasco J, Baillet AC, Ruutu M, et al. Interleukin-23 mediates the intestinal response to microbial $\beta$-1,3-glucan and the development of spondyloarthritis pathology in SKG mice. Arthritis Rheumatol. 2014;66:1755-67.

46. Jacques P, Lambrecht S, Verheugen E, Pauwels E, Kollias G, Armaka M, et al. Proof of concept: enthesitis and new bone formation in spondyloarthritis are driven by mechanical strain and stromal cells. Ann Rheum Dis. 2014;73:437-45.

47. Khmaladze I, Kelkka T, Guerard S, Wing K, Pizzolla A, Saxena A, et al. Mannan induces ROS-regulated, IL-17A-dependent psoriasis arthritis-like disease in mice. Proc Natl Acad Sci USA. 2014:111:E3669-78.

48. Jeong H, Bae EK, Kim H, Lim DH, Chung TY, Lee J, et al. Spondyloarthritis features in zymosan-induced SKG mice. Joint Bone Spine. 2017. https://doi.org/10.1016/j.jbspin.2017.11.008 (Epub 29 Nov 2017).

49. Coates LC, Kavanaugh A, Mease PJ, Soriano ER, Laura AcostaFelquer M, Armstrong AW, et al. Group for Research and Assessment of Psoriasis and Psoriatic Arthritis 2015 treatment recommendations for psoriatic arthritis. Arthritis Rheumatol. 2016;68:1060-71

50. Gossec L, Smolen JS, Ramiro S, de Wit M, Cutolo M, Dougados M, et al. European League Against Rheumatism (EULAR) recommendations for the management of psoriatic arthritis with pharmacological therapies: 2015 update. Ann Rheum Dis. 2016;75:499-510.

51. Elyoussfi S, Thomas BJ, Ciurtin C. Tailored treatment options for patients with psoriatic arthritis and psoriasis: review of established and new biologic and small molecule therapies. Rheumatol Int. 2016;36:603-12.

52. Sakkas LI, Bogdanos DP. Are psoriasis and psoriatic arthritis the same disease? The IL-23/IL-17 axis data. Autoimmun Rev. 2017;16:10-5.

53. Mease PJ, Gladman DD, Ritchlin CT, Ruderman EM, Steinfeld $\mathrm{SD}$, Choy EH, et al. Adalimumab for the treatment of patients with moderately to severely active psoriatic arthritis: results of a double-blind, randomized, placebo-controlled trial. Arthritis Rheum. 2005;52:3279-89.

54. Antoni C, Krueger GG, de Vlam K, Birbara C, Beutler A, Guzzo C, et al. Infliximab improves signs and symptoms of psoriatic arthritis: results of the IMPACT 2 trial. Ann Rheum Dis. 2005;64:1150-7. 
55. Kavanaugh A, McInnes I, Mease P, Krueger GG, Gladman D, Gomez-Reino J, et al. Golimumab, a new human tumor necrosis factor $\alpha$ antibody, administered every four weeks as a subcutaneous injection in psoriatic arthritis: twenty-four-week efficacy and safety results of a randomized, placebo-controlled study. Arthritis Rheum. 2009;60:976-86.

56. Kavanaugh A, Husni ME, Harrison DD, Kim L, Lo KH, Leu $\mathrm{JH}$, et al. Safety and efficacy of intravenous golimumab in patients with active psoriatic arthritis: results through week twenty-four of the GO-VIBRANT study. Arthritis Rheumatol. 2017;69:2151-61.

57. Sterry W, Ortonne JP, Kirkham B, Brocq O, Robertson D, Pedersen RD, et al. Comparison of two etanercept regimens for treatment of psoriasis and psoriatic arthritis: PRESTA randomised double blind multicentre trial. BMJ. 2010;340:c147.

58. Mease PJ, Fleischmann R, Deodhar AA, Wollenhaupt J, Khraishi M, Kielar D, et al. Effect of certolizumab pegol on signs and symptoms in patients with psoriatic arthritis: 24-week results of a phase 3 double-blind randomised placebo-controlled study (RAPID-PsA). Ann Rheum Dis. 2014;73:48-55.

59. Chandran V, Maharaj AB. Assessing disease activity in psoriasis and psoriatic arthritis: impact on management and therapy. Expert Rev Clin Immunol. 2016;12:573-82.

60. Olivieri I, Padula A, Scarano E, Scarpa R. Dactylitis or "sausageshaped" digit. J Rheumatol. 2007;34:1217-22.

61. Mease PJ. Measures of psoriatic arthritis: Tender and Swollen Joint Assessment, Psoriasis Area and Severity Index (PASI), Nail Psoriasis Severity Index (NAPSI), Modified Nail Psoriasis Severity Index (mNAPSI), Mander/Newcastle Enthesitis Index (MEI), Leeds Enthesitis Index (LEI), Spondyloarthritis Research Consortium of Canada (SPARCC), Maastricht Ankylosing Spondylitis Enthesis Score (MASES), Leeds Dactylitis Index (LDI), Patient Global for Psoriatic Arthritis, Dermatology Life Quality Index (DLQI), Psoriatic Arthritis Quality of Life (PsAQOL), Functional Assessment of Chronic Illness Therapy-Fatigue (FACIT-F), Psoriatic Arthritis Response Criteria (PsARC), Psoriatic Arthritis Joint Activity Index (PsAJAI), Disease Activity in Psoriatic Arthritis (DAPSA), and Composite Psoriatic Disease Activity Index (CPDAI). Arthritis Care Res (Hoboken). 2011;63(Suppl 11):S64-85.

62. Bakewell CJ, Olivieri I, Aydin SZ, Dejaco C, Ikeda K, Gutierrez $\mathrm{M}$, et al. Ultrasound and magnetic resonance imaging in the evaluation of psoriatic dactylitis: status and perspectives. J Rheumatol. 2013;40:1951-7.

63. D'Agostino MA, Terslev L. Imaging evaluation of the entheses: ultrasonography, MRI, and scoring of evaluation. Rheum Dis Clin N Am. 2016;42:679-93.

64. Kane D, Greaney T, Bresnihan B, Gibney R, FitzGerald O. Ultrasonography in the diagnosis and management of psoriatic dactylitis. J Rheumatol. 1999;26:1746-51.

65. Sudoł-Szopińska I, Matuszewska G, Kwiatkowska B, Pracoń G. Diagnostic imaging of psoriatic arthritis. Part I: etiopathogenesis, classifications and radiographic features. J Ultrason. 2016;16:65-77.

66. Kamel M, Eid H, Mansour R. Ultrasound detection of heel enthesitis: a comparison with magnetic resonance imaging. J Rheumatol. 2003;30:774-8.

67. Healy PJ, Groves C, Chandramohan M, Helliwell PS. MRI changes in psoriatic dactylitis: extent of pathology, relationship to tenderness and correlation with clinical indices. Rheumatology (Oxf). 2008;47:92-5.

68. Kaeley GS, Eder L, Aydin SZ, Gutierrez M, Bakewell C. Enthesitis: a hallmark of psoriatic arthritis. Semin Arthritis Rheum. 2018. https://doi.org/10.1016/j.semarthrit.2017.12.008 (Epub 6 Jan 2018).
69. Terslev L, Naredo E, Iagnocco A, Balint PV, Wakefield RJ, Aegerter P, et al. Defining enthesitis in spondyloarthritis by ultrasound: results of a Delphi process and of a reliability reading exercise. Arthritis Care Res (Hoboken). 2014;66:741-8.

70. Weinreb JH, Sheth C, Apostolakos J, McCarthy MB, Barden B, Cote MP, et al. Tendon structure, disease, and imaging. Muscles Ligaments Tendons J. 2014;4:66-73.

71. Gisondi P, Tinazzi I, El-Dalati G, Gallo M, Biasi D, Barbara LM, et al. Lower limb enthesopathy in patients with psoriasis without clinical signs of arthropathy: a hospital-based case-control study. Ann Rheum Dis. 2008;67:26-30.

72. Eder L, Jayakar J, Thavaneswaran A, Haddad A, Chandran V, Salonen D, et al. Is the MAdrid Sonographic Enthesitis Index useful for differentiating psoriatic arthritis from psoriasis alone and healthy controls? J Rheumatol. 2014;41:466-72.

73. Naredo E, Möller I, de Miguel E, Batlle-Gualda E, Acebes C, Brito E, et al. High prevalence of ultrasonographic synovitis and enthesopathy in patients with psoriasis without psoriatic arthritis: a prospective case-control study. Rheumatology (Oxf). 2011;50:1838-48.

74. Husni ME, Meyer KH, Cohen DS, Mody E, Qureshi AA. The PASE questionnaire: pilot-testing a psoriatic arthritis screening and evaluation tool. J Am Acad Dermatol. 2007;57:581-7.

75. Ibrahim GH, Buch MH, Lawson C, Waxman R, Helliwell PS. Evaluation of an existing screening tool for psoriatic arthritis in people with psoriasis and the development of a new instrument: the Psoriasis Epidemiology Screening Tool (PEST) questionnaire. Clin Exp Rheumatol. 2009;27:469-74.

76. Chandran V, Gladman DD. Toronto Psoriatic Arthritis Screening (ToPAS) questionnaire: a report from the GRAPPA 2009 annual meeting. J Rheumatol. 2011;38:546-7.

77. Karreman MC, Weel A, van der Ven M, Vis M, Tchetverikov I, Nijsten TEC, et al. Performance of screening tools for psoriatic arthritis: a cross-sectional study in primary care. Rheumatology (Oxf). 2017;56:597-602.

78. Kristensen S, Christensen JH, Schmidt EB, Olesen JL, Johansen $\mathrm{MB}$, Arvesen KB, et al. Assessment of enthesitis in patients with psoriatic arthritis using clinical examination and ultrasound. Muscles Ligaments Tendons J. 2016;6:241-7.

79. Marchesoni A, De Marco G, Merashli M, McKenna F, Tinazzi I, Marzo-Ortega H, et al. The problem in differentiation between psoriatic-related polyenthesitis and fibromyalgia. Rheumatology (Oxf). 2018;57:32-40.

80. Almodóvar R, Carmona L, Zarco P, Collantes E, González $\mathrm{C}$, Mulero J, et al. Fibromyalgia in patients with ankylosing spondylitis: prevalence and utility of the measures of activity, function and radiological damage. Clin Exp Rheumatol. 2010;28:S33-9.

81. Gladman DD. Clinical features and diagnostic considerations in psoriatic arthritis. Rheum Dis Clin N Am. 2015;41:569-79.

82. Orbai AM, de Wit M, Mease PJ, Callis Duffin K, Elmamoun $\mathrm{M}$, Tillett $\mathrm{W}$, et al. Updating the psoriatic arthritis (PsA) core domain set: a report from the PsA workshop at OMERACT 2016. J Rheumatol. 2017;44:1522-8.

83. Ferguson EG, Coates LC. Optimisation of rheumatology indices: dactylitis and enthesitis in psoriatic arthritis. Clin Exp Rheumatol. 2014;32:S-113-7.

84. Heuft-Dorenbosch L, Spoorenberg A, van Tubergen A, Landewé $\mathrm{R}$, van ver Tempel H, Mielants H, et al. Assessment of enthesitis in ankylosing spondylitis. Ann Rheum Dis. 2003;62:127-32.

85. Maksymowych WP, Mallon C, Morrow S, Shojania K, Olszynski WP, Wong RL, et al. Development and validation of the Spondyloarthritis Research Consortium of Canada (SPARCC) Enthesitis Index. Ann Rheum Dis. 2009;68:948-53. 
86. Healy PJ, Helliwell PS. Measuring dactylitis in clinical trials: which is the best instrument to use? J Rheumatol. 2007;34:1302-6.

87. Mumtaz A, Gallagher P, Kirby B, Waxman R, Coates LC, Veale JD, et al. Development of a preliminary composite disease activity index in psoriatic arthritis. Ann Rheum Dis. 2011;70:272-7.

88. Mease PJ, van der Heijde D, Ritchlin CT, Okada M, Cuchacovich RS, Shuler CL, et al. Ixekizumab, an interleukin-17A specific monoclonal antibody, for the treatment of biologic-naive patients with active psoriatic arthritis: results from the 24-week randomised, double-blind, placebo-controlled and active (adalimumab)-controlled period of the phase III trial SPIRITP1. Ann Rheum Dis. 2017;76:79-87.

89. Mease PJ, Gottlieb AB, van der Heijde D, FitzGerald O, Johnsen A, Nys M, et al. Efficacy and safety of abatacept, a T-cell modulator, in a randomised, double-blind, placebo-controlled, phase III study in psoriatic arthritis. Ann Rheum Dis. 2017;76:1550-8.

90. Gladman D, Rigby W, Azevedo VF, Behrens F, Blanco R, Kaszuba A, et al. Tofacitinib for psoriatic arthritis in patients with an inadequate response to TNF inhibitors. N Engl J Med. 2017;377:1525-36

91. Mease PJ, Karki C, Palmer JB, Etzel CJ, Kavanaugh A, Ritchlin $\mathrm{CT}$, et al. Clinical characteristics, disease activity, and patientreported outcomes in psoriatic arthritis patients with dactylitis or enthesitis: results from the Corrona Psoriatic Arthritis/ Spondyloarthritis Registry. Arthritis Care Res (Hoboken). 2017;69:1692-9.

92. Lee S, Mendelsohn A, Sarnes E. The burden of psoriatic arthritis: a literature review from a global health systems perspective. P T. 2010;35:680-9.

93. Polachek A, Cook R, Chandran V, Gladman DD, Eder L. The association between sonographic enthesitis and radiographic damage in psoriatic arthritis. Arthritis Res Ther. 2017;19:189.

94. Geijer M, Lindqvist U, Husmark T, Alenius GM, Larsson PT, Teleman A, et al. The Swedish Early Psoriatic Arthritis Registry 5-year followup: substantial radiographic progression mainly in men with high disease activity and development of dactylitis. J Rheumatol. 2015;42:2110-7.

95. Kivelevitch D, Mansouri B, Menter A. Long term efficacy and safety of etanercept in the treatment of psoriasis and psoriatic arthritis. Biologics. 2014;8:169-82.

96. McGonagle D, Tan AL, Benjamin M. The nail as a musculoskeletal appendage: implications for an improved understanding of the link between psoriasis and arthritis. Dermatology. 2009;218:97-102.
97. Sudoł-Szopińska I, Kwiatkowska B, Prochorec-Sobieszek M, Pracoń G, Walentowska-Janowicz M, Maśliński W. Enthesopathies and enthesitis. Part 2: imaging studies. J Ultrason. 2015;15:196-207.

98. Balakrishnan C, Madnani N. Diagnosis and management of psoriatic arthritis. Indian J Dermatol Venereol Leprol. 2013;79(Suppl 7):S18-24.

99. Mancarella L, Battaglia M, Addimanda O, Pelotti P, Galletti S, Meliconi R. Successful adalimumab treatment of HLA B27 negative heel enthesitis documented with MRI and US. Clin Exp Rheumatol. 2010;28:443-4.

100. Olivieri I, Barozzi L, Favaro L, Pierro A, de Matteis M, Borghi $\mathrm{C}$, et al. Dactylitis in patients with seronegative spondylarthropathy. Assessment by ultrasonography and magnetic resonance imaging. Arthritis Rheum. 1996;39:1524-8.

101. Batmaz I, Sariyildiz MA, Özçakar L. Ultrasound imaging for prompt monitorization of the treatment response in patients with multi-joint involvement. West Indian Med J. 2015;64:459.

102. McInnes IB, Kavanaugh A, Gottlieb AB, Puig L, Rahman P, Ritchlin C, et al. Efficacy and safety of ustekinumab in patients with active psoriatic arthritis: 1 year results of the phase 3, multicentre, double-blind, placebo-controlled PSUMMIT 1 trial. Lancet. 2013;382:780-9.

103. Deodhar A, Gottlieb A, Boehncke WH, Dong B, Wang Y, Barchuk W, et al. OP0218 efficacy and safety results of guselkumab, an anti-IL23 monoclonal antibody, in patients with active psoriatic arthritis over 24 weeks: a phase $2 \mathrm{a}$, randomized, doubleblind, placebo-controlled study [abstract]. Ann Rheum Dis. 2017;76(Suppl 2):142-3.

104. Nash P, Kirkham B, Okada M, Rahman P, Combe B, Burmester $\mathrm{GR}$, et al. Ixekizumab for the treatment of patients with active psoriatic arthritis and an inadequate response to tumour necrosis factor inhibitors: results from the 24-week randomised, doubleblind, placebo-controlled period of the SPIRIT-P2 phase 3 trial. Lancet. 2017;389:2317-27.

105. McInnes IB, Mease PJ, Kirkham B, Kavanaugh A, Ritchlin CT, Rahman P, et al. Secukinumab, a human anti-interleukin17A monoclonal antibody, in patients with psoriatic arthritis (FUTURE 2): a randomised, double-blind, placebo-controlled, phase 3 trial. Lancet. 2015;386:1137-46.

106. Kavanaugh A, Mease PJ, Gomez-Reino JJ, Adebajo AO, Wollenhaupt J, Gladman DD, et al. Treatment of psoriatic arthritis in a phase 3 randomised, placebo-controlled trial with apremilast, an oral phosphodiesterase 4 inhibitor. Ann Rheum Dis. 2014;73:1020-6. 